\title{
PERBEDAAN PENGARUH METODE PEMBELAJARAN SIMULASI DENGAN LATIHAN (DRILL) TERHADAP PENERAPAN PENGISIAN PARTOGRAF PADA MAHASISWA DIII KEBIDANAN
}

\author{
Triwik Sri Mulati, Kuswati, dan Aprilinawati Sri Rejeki \\ Poltekes Surakarta \\ email: triwiksrimulati@ymail.com
}

\begin{abstract}
Abstrak: Tujuan penelitian ini adalah mengetahui perbedaan pengaruh metode pembelajaran simulasi dengan latihan terhadap penerapan pengisian partograf pada mahasiswa DIII Kebidanan. Rancangan penelitian ini adalah eksperimen semu dengan desain randomized pretest posttest comparison group design dan metode analisis data yang digunakan adalah uji Wilcoxon pada kelompok pretes-postes masing-masing kelompok dan uji beda menggunakan uji U Mann-Whitney. Sampel dalam penelitian adalah seluruh mahasiswa semester III Akbid Estu Utomo Boyolali sejumlah 90 orang, yang dibagi dalam kelompok ekperimen (metode simulasi) sejumlah 45 orang dan pada kelompok kontrol (latihan) sebanyak 45 orang. Hasil penelitian ini menunjukkan terdapat perbedaan pengaruh yang signifikan antara kelompok latihan (drill) dan kelompok simulasi dengan nilai z:-3,413 dan $\mathrm{p}$ value:0,001 ( $\alpha=$ 0.05), dimana kelompok simulasi lebih berpengaruh daripada kelompok latihan (drill).
\end{abstract}

\section{Kata Kunci: metode simulasi, metode latihan, pengisian partograf}

\section{THE DIFFERENCE OF THE INFLUENCE BETWEEN THE SIMULATION AND THE DRILLING METHODS IN PARTOGRAPH FILLING AT DIPLOMA III MIDWIFERY STUDENTS}

\begin{abstract}
The aim of this research was to know the difference of the influence between the simulation and the drilling methods in partograph filling at Diploma III midwifery students. This research was quasi experiment with the randomized pretest posttest comparison group design. The data were analyzed using Wilcoxon test and U Mann-Whitneytest. The sample was Estu Utomo Midwifery Academy students consisting of 90 students divided into one experimental group consisting of 45 students and one control group consisting of 45 students. The findings showed that there was a significant difference in the influence between the drill group and the simulation group with $\mathrm{z}=-3.413$ and $\mathrm{p}=0.001$ $(\alpha=0.05)$. This meant that the simulation method was more influential than the drilling method in partographfilling.
\end{abstract}

Keywords: simulation method, drilling method, partograph filling

\section{PENDAHULUAN}

Proses belajar-mengajar merupakan suatu kegiatan dalam rangka melaksanakan kurikulum suatu lembaga pendidikan agar dapat memengaruhi para siswa mencapai tujuan pendidikan yang telah ditetapkan. Dalam melaksanakan proses pembelajaran diperlukan seperangkat komponen pengajaran yang di dalamnya mencakup tujuan, bahan, metodologi, dan penilaian. Metodologi pengajaran adalah metode dan teknik yang digunakan guru (pendidik) dalam melakukan interaksi dengan siswa (terdidik) agar bahan pengajaran sampai kepada siswa (terdidik), sehingga mereka menguasai tujuan pengajaran (Sudjana, 2002). Senjaya (2008:25) mengemukakan bahwa strategi merupakan "a plan of operation something" yang berarti rencana dari suatu kegiatan, sedangkan metode adalah " $a$ way in achieving something" yang berarti cara dalam mencapai sesuatu. Dengan demikian, suatu strategi dapat dilaksanakan dengan berbagai metode.

Metode pembelajaran simulasi merupakan metode belajar yang memberikan kesempatan kepada mahasiswa untuk mengetahui suatu proses dengan memindahkan situasi nyata 
ke dalam ruang kelas. Sebagai mana ditunjukkan Depdiknas (2005:133), metode pembelajaran simulasi adalah bentuk metode praktik yang sifatnya untuk mengembangkan keterampilan peserta didik (ranah kognitif maupun keterampilan). Metode ini memindahkan suatu situasi yang nyata ke dalam kegiatan atau ruang belajar karena adanya kesulitan atau keterbatasan untuk melakukan praktik di dalam situasi yang sesungguhnya. Metode latihan adalah suatu metode mengajar dengan memberikan pelatihan keterampilan kepada peserta didik. Metode ini bertujuan untuk membentuk kebiasaan atau pola yang otomatis pada peserta didik (Simamora, 2009). Tetapi, kelemahan metode latihan adalah kurang mengembangkan bakat/ inisiatif siswa/mahasiswa untuk berpikir.

Pendidikan diploma III kebidanan merupakan pendidikan vokasional yang menghasilkan bidan pelaksana dengan gelar Ahli Madya Kebidanan (A. Md. Keb), dengan beban studi sekurang-kurangnya 110 (seratus sepuluh) SKS dan sebanyak-banyaknya 120 SKS (Kepmendiknas 232/U/2000). Salah satu mata kuliah yang disampaikan kepada mahasiswa adalah Asuhan Kebidanan Persalinan yang di dalamnya terdapat sub mata kuliah partograf.

Partograf merupakan alat bantu untuk membuat keputusan klinik, memantau, mengevaluasi dan menatalaksana persalinan. Partograf dapat digunakan untuk mendeteksi masalah dan penyulit sesegera mungkin dan merujuk ibu dalam kondisi gawat darurat (Depkes, 2008). Partograf mempunyai manfaat yang begitu mendasar dalam memberikan layanan kebidanan.

Berdasarkan studi pendahuluan yang dilakukan di Akademi Kebidanan Estu Utomo Boyolali, metode pembelajaran yang digunakan dalam penerapan pengisian partograf pada mata kuliah Asuhan Persalinan menggunakan metode latihan (driil). Dari evaluasi hasil tes pengisian partograf diketahui nilai rata-rata mahasiswa semester III tahun akademik 2010/ 2011 adalah 84,85 . Namun, hasil wawancara kepada 10 mahasiswa, 4 di antaranya mengatakan masih bingung dalam mengisi patograf. Oleh karena itu, metode simulasi mungkin akan lebih baik jika diterapkan para dosen dalam proses belajar mengajar, khususnya tentang pengisian patograf karena mahasiswa lebih berperan aktif dan berlatih peran untuk memahami suatu konsep atau keterampilan.

Tujuan dalam penelitian ini adalah untuk mengetahui perbedaan pengaruh metode pembelajaran simulasi dengan latihan (drill) terhadap penerapan pengisian partograf pada mahasiswi DIII kebidanan.

Secara umum, hasil penelitian ini diharapkan dapat memberikan informasi apakah hasil pembelajaran pengisian partograf dalam mata kuliah Asuhan Persalinan dengan metode simulasi lebih baik daripada metode latihan (drill). Secara lebih rinci, hasil penelitian ini diharapkan dapat memberikan masukan bagi para tenaga pengajar di institusi kebidanan mengenai implementasi metode simulasi dalam mata kuliah Asuhan Persalinan sub mata kuliah partograf.

Metode simulasi adalah cara penyajian pengalaman belajar dengan menggunakan situasi tiruan untuk memahami tentang konsep, prinsip, atau keterampilan tertentu. Simulasi dapat digunakan sebagai metode mengajar dengan asumsi tidak semua proses pembelajaran dapat dilakukan secara langsung pada objek yang sebenarnya (Depdiknas, 2008). Metode simulasi bertujuan untuk melatih keterampilan tertentu, baik bersifat profesional maupun bagi kehidupan sehari-hari, memperoleh pemahaman tentang suatu konsep atau prinsip, melatih memecahkan masalah, meningkatkan keaktifan belajar, memberikan motivasi belajar kepada siswa, melatih siswa untuk mengadakan kerjasama dalam situasi kelompok, menumbuhkan daya kreatif siswa, dan melatih siswa untuk mengembangkan sikap toleransi (Depdiknas, 2008).

Anitah, dkk. (2007: 523) menyebutkan prosedur yang harus ditempuh dalam penggunaan metode simulasi sebagai berikut. (1) Penetapan topik simulasi yang diarahkan oleh guru. (2) Menetapkan kelompok dan topik-topik yang akan dibahas. (3) Simulasi diawali dengan petunjuk dari guru tentang prosedur, teknik, dan peran yang dimainkan. (4) Proses pengamatan pelaksanaan simulasi dapat dilaku- 
kan dengan diskusi. (5) Pengadaan kesimpulan dan saran dari hasil kegiatan simulasi.

Berikut ini kelebihan metode simulasi. (1) Memperkaya pengetahuan, sikap, keterampilan, serta pengalaman yang tidak langsung diperlukan dalam menghadapi berbagai masalah. (2) Peserta didik berkesempatan untuk menyalurkan perasaan yang terpendam sehingga mendapat kepuasan, kesegaran, dan kesehatan jiwa. (3) Melalui simulasi dapat dikembangkan bakat dan kemampuan yang mungkin dimiliki peserta didik, misalnya dalam seni drama, bermain peran dan sebagainya (Nursalam, 2008:4) serta dapat meningkatkan keaktifan belajar siswa (FIP-UPI, 2007). Di pihak lain, kekurangan metode simulasi sebagai berikut. (1) Pengalaman yang diperoleh melalui simulasi tidak selalu tepat dan sempurna dengan kenyataan di lapangan atau dalam kehidupan. (2) Simulasi dipengaruhi faktor-faktor emosional sepert rasa malu, ragu-ragu, atau takut yang dapat mempengaruhi peserta didik dalam melakukan simulasi. (3) Simulasi memerlukan pengelompokkan peserta didik yang fleksibel (Nursalam, 2008).

Metode latihan adalah suatu metode mengajar dengan memberikan pelatihan keterampilan kepada peserta didik. Metode ini bertujuan untuk membentuk kebiasaan atau pola yang otomatis pada peserta didik (Simamora, 2009).

Metode latihan dalam praktekknya memunyai beberapa kelebihan seperti berikut. (1) meningkatkan kecakapan motorik, seperti menulis, melafalkan huruf, membuat dan menggunakan alat-alat. (2) Meningkatkan kecakapan mental, seperti penjumlahan, pembagian, tanda-tanda simbol. (3) Dapat membentuk kebiasaan dan meningkatkan ketepatan dan kecepatan pelaksanaan. Sebaliknya, kelemahan dari metode latihan yaitu: (1) menghambat bakat dan inisiatif peserta didik karena hanya membentuk kebiasaan bukan keterampilan analisis; (2) menimbulkan penyesuaian secara statis kepada lingkungan; dan (3) dapat menimbulkan verbalisme (Simamora, 2009).

\section{METODE}

Rancangan dalam penelitian ini menggunakan eksperimen semu dengan desain randomized pretest posttest comparison group design. Sampel dalam penelitian ini adalah seluruh mahasiswi semester III Akbid Estu Utomo Boyolali sejumlah 90 orang. Sampel dibagi menjadi dua kelompok, yaitu (1) kelompok eksperimen yang berjumlah 45 orang dan diberikan perlakuan metode pembelajaran simulasi; dan (2) kelompok kontrol yang berjumlah 45 orang dengan metode pembelajaran latihan (drill) yang merupakan metode yang sudah biasa digunakan dalam pembelajaran partograf.

Penelitian ini menggunakan dua variabel, yait variable bebas dan variable terikat. Variabel bebas (independent) berupa metode latihan (drill) dan simulasi. Variabel terikat berupa penerapan pengisian partograf.

Pembelajaran dengan metode latihan (drill) adalah mengerjakan soal kasus partograf. Penggunaan metode ini diawali dengan penjelasan cara mengisi dalam mata kuliah Asuhan Persalinan yang dikeluarkan oleh Dinas Kesehatan Jawa Tengah, dengan bimbingan dan arahan peneliti sesuai Rencana Pelaksanaan Pembelajaran yang telah disiapkan sebelumnya. Pembelajaran dengan metode latihan (drill) dilakukan setelah mahasiswa selesai mengisi pretest dan pada akhir pembelajaran dilakukan posttest dengan waktu masing-masing 10 menit.

Metode simulasi adalah cara penyajian pengalaman belajar dengan menggunakan situasi tiruan, yaitu mahasiswa berlatih peran menjadi bidan saat proses observasi ibu bersalin kala I. Hal ini dilakukan untuk memahami konsep penerapan pengisian partograf dengan arahan dari skenario kasus observasi yang telah disiapkan yang disampaikan sesuai Rencana Pelaksanaan Pembelajaran. Pembelajaran dengan metode simulasi dilakukan setelah mahasiswa selesai mengisi pretest dan pada akhir pembelajaran dilakukan posttest dengan waktu masing-masing 10 menit.

Definisi operasional penerapan pengisian partograf yaitu hasil pengisian partograf yang terdiri dari 20 point seperti berikut. 
- Data pasien meliputi nama, umur istri dan suami.

- Gravida, para, abortus dan usia kehamilan.

- Waktu/ jam datang dan tanggal.

- Waktu pecahnya selaput ketuban.

- Mulai terasa mules/ kenceng-kenceng.

- DJJ dibuat kurve.

- Air ketuban diberi kode yang sesuai.

- Penyusupan (Moulase) kepala janin dikode sesuai.

- Pembukaan serviks dicatat dan dikode sesuai kasus.

- Penurunan bagian terendah janin dikode sesuai.

- Waktu (jam) pemeriksaan dicatat.

- Kontraksi uterus dilukis sesuai kasus.

- Pemberian oksitosin dicatat (kalau ada).

- Obat-obatan lainnya dan cairan IV yang diberikan.

- Nadi dibuat kurve.

- Tekanan darah dicatat dan dilukis (systole/ diastole).

- Suhu dicatat.

- Urine dicatat.

- Makan dan minum terakhir serta jumlah porsinya. Tanda tangan penolong.

- Keterangan BBL.

Instrumen dalam penelitian ini adalah partograf, yang berisi soal kasus pemantauan atau observasi kala I persalinan yang dikeluarkan oleh Dinas Kesehatan Jawa Tengah. Butirbutir penilaian partograf berbentuk checklist serta lembar rekapan skor pengisian partograf. Poin-poin yang terdapat dalam checklist diambil dari checklist pengisian partograf yang dikeluarkan oleh Dinas Kesehatan Jawa Tengah yang dijabarkan sesuai kebutuhan penilitian, tanpa menambah atau mengurangi hal-hal yang harus ada dalam pengisian partograf. Jawaban benar bernilai 1 dan jawaban salah bernilai 0 .

Teknik analisis data yang digunakan adalah uji Wilcoxon yang diambil dari nilai pretest-posttest masing-masing kelompok dan uji beda menggunakan uji U Mann-Whitney yang dihitung dengan bantuan komputer program SPSS Versi 16.

\section{HASIL DAN PEMBAHASAN}

Sebelum data dianalisis, terlebih dahulu dilakukan uji persyaratan analisis, yaitu uji normalitas. Hasil uji normalitas berdasarkan data yang ada dengan menggunakan uji Kolmogorov Smirnov, menunjukkan bahwa semua data memunyai nilai Asymp.Sig (2-tailed) < 0,05. Hal itu menunjukkan bahwa data berdistribusi tidak normal sehingga dilanjutkan dengan menggunakan uji statistik nonparametrik. Penelitian ini menggunakan uji Wilcoxon pada kelompok pretest-posttest masing-masing kelompok, dan uji U Mann-Whitnet untuk kelompok kontrol dan kelompok eksperimen.

\section{Hasil Penelitian}

Data hasil penelitian baik pretes maupun postes kelompok eksperimen dan kontrol setelah dianalisis disajikan pada Tabel 1 sampai dengan Tabel 4.

Tabel 1. Data Deskriptif Kelompok Eksperimen (Simulasi)

\begin{tabular}{ccc}
\hline & N & Mean \\
\hline Pretes & 45 & 6.31 \\
Postes & 45 & 18.16 \\
\hline
\end{tabular}

Tabel 2. Data Deskriptif Kelompok Kontrol (Latihan)

\begin{tabular}{ccc}
\hline & N & Mean \\
\hline Pretes & 45 & 6.38 \\
Postes & 45 & 15.49 \\
\hline
\end{tabular}

Tabel 3. Analisis Uji Wilcoxon terhadap Pretes dan Postes Kelompok Eksperimen dan Kelompok Kontrol

\begin{tabular}{lccc}
\hline Kelompok & $\mathrm{Z}$ & $\mathrm{p}$ value & Kesimpulan \\
\hline $\begin{array}{l}\text { Eksperimen } \\
\text { (simulasi) }\end{array}$ & -5.861 & 0,000 & Signifikan \\
$\begin{array}{l}\text { Kontrol } \\
\text { (latihan) }\end{array}$ & -5.849 & 0.000 & Signifikan \\
\hline
\end{tabular}


Tabel 4. Analisis Uji U Mann-Whitney terhadap Kelompok Ekperimen dan Kontrol (Pretes dan Postes)

\begin{tabular}{ccc}
\hline Mean & $\mathrm{Z}$ & $\mathrm{p}$ value \\
\hline 54.79 (kelompok eksperimen) & & \\
36.21 (kelompok kontrol & -3.413 & .001 \\
\hline
\end{tabular}

Hasil uji statistik dengan uji U MannWhitney menunjukkan terdapat perbedaan pengaruh antara kelompok eksperimen (metode simulasi) dan kontrol (metode latihan), dengan Asymp. Sig. (2-tailed) $0.001<0.05$.

\section{Pembahasan}

Hasil penelitian menunjukkan sejumlah 7 responden memiliki skor 20 (nilai sempurna) pada kelompok kontrol yang dibelajarkan lewat metode pembelajaran latihan/drill. Pada kelompok eksperimen yang dibelajarkan lewat metode simulasi terdapat 14 responden yang mendapatkan skor 20 (nilai sempurna). Data tersebut menunjukkan bahwa mahasiswa (responden) yang mendapat nilai sempurna (skor 20) lebih banyak pada kelompok yang diberi metode pembelajaran simulasi dibanding kelompok yang diberi metode pembelajaran latihan/drill. Hal ini sesuai dengan teori yang dikemukakan oleh Depdiknas (2008) bahwa metode simulasi adalah cara penyajian pengalaman belajar dengan menggunakan situasi tiruan supaya mahasiswa dapat memahami secara maksimal tentang keterampilan tertentu, khususnya dalam penelitian ini adalah keterampilan pengisian partograf.

Kebidanan termasuk pendidikan vokasional sehingga banyak keterampilan yang harus dikuasai oleh mahasiswa kebidanan. Mahasiswa diharapkan sudah terampil saat mereka diterjunkan praktik di tempat praktik (Rumah Sakit, Bidan Praktik Mandiri, atau Puskesmas). Sebelum diterjunkan ke tempat praktik, mahasiswa dilatih keterampilan di laboratorium kampus terlebih dahulu karena mahasiswa tidak boleh mengasuh pasien/klien langsung sebelum mereka dinyatakan lulus pembelajaran laboratorium.
Dengan demikian, perlu suatu metode pembelajaran yang dapat menyajikan situasi yang mendekati situasi nyata seperti di tempat praktik. Salah satu metode pembelajaran yang dapat digunakan dalam proses pembelajaran laboratorium kebidanan adalah simulasi. Hal ini sesuai dengan teori yang dikemukakan oleh Depdiknas (2008) bahwa simulasi dapat digunakan sebagai metode mengajar dengan asumsi tidak semua proses pembelajaran dapat dilakukan secara langsung pada objek yang sebenarnya.

Pengalaman mahasiswa (responden) yang diperoleh melalui simulasi, ketika mereka berperan sebagai seorang bidan yang sedang menghadapi ibu yang akan bersalin, melakukan pemeriksaan dan pemantauan keadaan ibu serta mencatat hasil pemeriksaan ke dalam partograf, dapat digunakan sebagai media dalam proses pembelajaran. Hal tersebut terbukti berhasil meningkatkan keterampilan mahasiswa (responden) dalam pengisian partograf. Hal ini sesuai dengan teori yang dikemukakan oleh Sanjaya (2011) bahwa penggunaan media dalam proses belajar mengajar dapat merangsang kegiatan belajar peserta didik, mengalirkan pesan, yang pada akhirnya dapat meningkatkan prestasi belajar peserta didik.

Masing-masing metode pembelajaran memiliki kelebihan dan kekurangan. Tidak ada metode pembelajaran yang terbaik, tetapi sebaiknya penggunaan metode dalam pembelajaran disesuaikan dengan tujuan dari pembelajaran yang akan dicapai agar lebih efektif dan memiliki hasil signifikan. Metode pembelajaran yang biasa diterapkan di tempat penelitian pada mata kuliah Asuhan Kebidanan persalinan subbab partograf adalah dengan metode latihan (drill).

Hasil penelitian menunjukkan bahwa analisa dengan uji Wilcoxon terhadap kelompok kontrol terdapat pengaruh yang signifikan antara pretest dan posttest dengan metode latihan (drill) (z: -5.849 dan p value: 0.000). Salah satu kelebihan dari metode latihan adalah dapat membentuk kebiasaan dan meningkatkan ketepatan dan kecepatan pelaksanaan. Kelemahannya, metode ini membentuk kebiasaan atau pola yang otomatis pada peserta didik yang cenderung membuat peserta didik kurang men- 
dapat pemahaman dan kurang mengembangkan inisiatif untuk berpikir (Simamora, 2009).

Pada uji Wilcoxon terhadap kelompok eksperimen menunjukkan adanya pengaruh yang signifikan antara pretes dan posttes dengan pemberian metode pembelajaran simulasi (z: 5.869 dan p value: 0.000). Hasil penelitian dengan uji $U$ Mann-Whitney menunjukkan terdapat perbedaan antara kelompok kontrol dan eksperimen dengan $p$ value $0.001(\alpha=0.05)$, sehingga $\mathrm{p}$ value $<\alpha$, yang berarti ada pengaruh yang signifikan pada metode pembelajaran simulasi.

Berdasarkan data tersebut, dapat disimpulkan bahwa metode pembelajaran simulasi lebih efektif daripada metode pembelajaran latihan (drill) terhadap penerapan pengisian partograf pada mahasiswa DIII Kebidanan Semester III di Akademi Kebidanan Estu Utomo Boyolali. Hal ini terjadi karena metode simulasi bertujuan untuk meningkatkan keaktifan belajar mahasiswa, memberikan motivasi belajar, menumbuhkan daya kreatifitas sehingga mereka mendapatkan pemahaman yang lebih dalam tentang materi pembelajaran, khususnya tentang pengisian partograf (Depdiknas, 2008).

Dalam pengisian partograf, setelah mahasiswa dapat memahami materi, diharapkan mereka juga dapat mengisi partograf dengan cepat dan tepat karena aplikasi pengisian partograf dalam proses pembelajaran khususnya pada uji kompetensi dibatasi waktu hanya selama 10 menit. Oleh karena itu, mahasiswa perlu dibekali keterampilan pengisian partograf. Salah satu metode pembelajaran yang cukup efektif untuk diterapkan dalam meningkatkan keterampilan mahasiswa dalam pengisian partograf adalah metode simulasi, di samping metode latihan (drill).

\section{PENUTUP}

\section{Kesimpulan}

Hasil penelitian ini dapat disimpulkan bahwa terdapat perbedaan pengaruh yang signifikan antara kelompok latihan (drill) dan kelompok simulasi dengan nilai z:-3,413 dan $\mathrm{p}$ value:0,001 $(\alpha=0.05)$. Hal itu menunjukkan bahwa kelompok yang dibelajarkan dengan me- tode simulasi lebih berpengaruh daripada kelompok latihan (drill) terhadap penerapan pengisian partograf pada mahasiswa DIII Kebidanan.

\section{Saran}

Saran yang disampaikan kepada para pendidik DIII Kebidanan agar dapat mengkolaborasikan dua metode pembelajaran dalam pengisian partograf, yaitu metode simulasi untuk meningkatkan keterlibatan mahasiswa dalam proses belajar sehingga meningkatkan pemahaman dan keterampilan mahasiswa, dan metode latihan (drill) untuk membiasakan mahasiswa mengisi partograf pada mata kuliah Asuhan Kebidanan Persalinan.

\section{UCAPAN TERIMAKASIH}

Penulis mengucapkan terima kasih kepada sponsor penelitian ini, Dewan Redaksi dan Staf Jurnal Cakrawala Pendidikan yang telah memberi kesempatan terpublikasinya hasil penelitian ini, serta kepada semua pihak yang telah membantu terlaksananya penelitian ini.

\section{DAFTAR PUSTAKA}

Anitah, Sri W., dkk. 2007. Strategi Pembelajaran di SD. Jakarta: Universitas Terbuka.

Depdiknas. 2005. Kumpulan Metode Pembelajaran/Pendamping. http.www.media. diknas.go.id/media/document/3553.pdf. Diunduh Tanggal 13 Mei 2012.

Depdiknas. 2008. Strategi Pembelajaran dan Pemilihannya. Jakarta: Direktorat Jenderal Peningkatan Mutu Pendidik dan Tenaga Kependidikan.

Dinas Kesehatan Jawa Tengah. 2007. Kumpulan Soal UAP DIII Kebidanan. Jawa Tengah: Dinas Kesehatan.

Kep. Mendiknas. 2000. Pedoman Penyusunan Kurikulum Pendidikan Tinggi dan Penilaian Hasil Belajar mahasiswa. Jakarta: Mendiknas. 
Sanjaya, Wina. 2011. Strategi Pembelajaran Berorientasi Standar Proses Pendidikan. Jakarta: Kencana Prenada Media.

Simamora, Roymond H. 2009. Buku Ajar Pendidikan dalam Keperawatan. Jakarta: EGC.
Sudjana, Nana. 2002. Cara Belajar Siswa Aktif dalam Proses Belajar Mengajar. Bandung: Sinar Baru. 